Vol. 1, No. 1, 2020

https://doi.org/

UDK 534.843:004.9

O. Belej, K. Kolesnyk,

${ }^{1}$ Lviv Polytechnic National University

\title{
APPL YING SMARTPHONES FOR POSITIONING IN THE MIDDLE OF THE ROOM
}

(C) Belej O., Kolesnyk K., 2020

The article deals with the problem of navigating indoors in conditions of satellite signal unavailability. In this case, alternative sources of positioning are used to determine the location of the objects. Use for navigation tasks inside the premises of the smartphone allows you to get comprehensive data on its operation. To solve the problem of navigation, the most important elements of the data sets is the unique identifier of the monitored device and the relative power level of the signal received from it. The data of the calculations and experiments show that the navigation measurements with the help of smartphones allow to qualitatively solve the problem of observation at given distances between sensors not exceeding 5-7 meters. The relative position of the sensors and the moving objects is important. At a distance of $5 \mathrm{~m}$ from the beacons and the object, the actual accuracy of the object coordinates is 1-2 $\mathrm{m}$, which is sufficient for traditional navigation tasks in the middle of buildings.

Keywords - information system, indoor navigation, sensors, smartphone, signal, coordinates, speed, least-squares method.

\section{Relevance of research}

Two decades ago, the task of navigation was solved almost exclusively by its special and industry interests. After the advent of the mass entry into the life of modern smartphones, there has been a qualitative leap, and now the interest in navigation tasks is manifested by a very wide range of household consumers.

Indoors are not always available traditional sources of navigation data - second-generation satellite navigation systems. In this case, alternative sources of navigation information are used to determine the location of the objects: inertial navigation means (accelerometers, gyroscopes), Wi-Fi hotspots, Bluetooth data devices, pressure transducer, magnetometer. Their data can be used individually or collectively, depending on the task being solved.

To date, navigation inside rooms has become a separate class of tasks [1]. In terms of information technology, these tasks are complex. First, they require the development of specific mathematical models and fundamental algorithms to provide the navigation component. Secondly, their implementation in the form of information services requires the development of software complexes of special architecture, which takes into account the features of software and hardware platforms of mobile devices.

Despite the increased interest in the problem of navigating indoors by researchers and developers, it can be said that standard methods for solving it have not been developed to date; this creates the prospect of innovation. The following well-proven approaches are available in the field of indoor navigation.

When using data from inertial sensors with the help of gyroscopes and accelerometers of a mobile device, different options of inertial navigation problems are solved [2]. The advantage of this approach is the autonomy and the lack of attachment to external infrastructure. However, household appliances inertial measurements are only available with a large margin of error, which makes this approach practically useful only for special devices equipped with high precision navigation sensors.

The first way to use such data is to solve the problem of the trilateration type. In this case, the measurement of the distances of the object sensor is the source data for estimating the coordinates of the 
observed object. The distance is estimated by the level of signal received by the mobile device [3]. This method is similar to that used, in particular, in hydroacoustics [4]. Another way is to determine the location of the object by comparing the measured signal levels from the surrounding sensors with the pre-measured values attached to the room map [5,6]. The advantages of the approach include the possibility of using already deployed data networks (Wi-Fi). The disadvantage is the high error of measuring the signal level, the discreteness of the data maps of the signal level, in principle limits the accuracy of navigation, and the need for pre-calibration and adjustment (training) of the system.

Attempts have been made to develop other approaches, such as an optical type system when comparing room scan data and images from a smartphone camera [7] or a magnetic field-based system using a smartphone compass [8], and combining them in one system positioning of several approaches simultaneously $[9,10]$.

Use for indoor navigation tasks with Bluetooth devices has a number of advantages: the ability to build infrastructure based on inexpensive and widespread equipment that does not require specialized professional skills, and the ability of virtually arbitrary configuration of sensors on the walls of the room due to their small size and autonomy. In addition, the range of visibility of Bluetooth devices is small, and their signal is practically not passed through the capital walls, which completely solves the "floor problem" [11].

Recently, the problem of navigating indoors (indoor navigation) of a large area and complex configuration, such as airport terminals, shopping centers, warehouses, has become urgent. Due to the great commercial prospects, the direction of indoor navigation is becoming more in demand and has already attracted the attention of such large companies like Google, Apple, Qualcomm, Broadcom, Sony, and millions of dollars have already been invested in this promising direction, and the results of the developments have been published in several works $[12,13]$. The methods proposed by developers for positioning or navigating within bulky buildings can be divided into two groups: navigators based on sensors and communication modules already available in smartphones, and fundamentally new devices requiring new hardware and software [14].

The authors set out to implement a comprehensive navigation system (CNS) based on hardwarebased sensors, computers (processors) and communication modules built into the smartphone. The basis for this should be the autonomous way of calculating the path, and its increasing time positioning error must be corrected by positioning data from the network of Bluetooth beacons. To obtain navigation information using inertial micromechanical sensors and related software algorithms, you can use the algorithms of the navigation system or a simpler advanced algorithm for calculating steps. Obtaining corrective positional information from the Bluetooth beacon network can be done using the traditional trilateral method. Thus, the main focus of the work was the development of a system for positioning moving objects on the base of the hardware of the smartphone, and the experimental development of the positioning system to find the most effective composition and method of use.

This paper examines a model of indoor navigation based on data from Bluetooth devices, based on the measurement of the signal level that interprets the object-sensor range. The purpose of the work is to evaluate the characteristic accuracy of determining the coordinates of the object in different navigation situations and the prospects of implementing the approach for particular applications.

\section{The formulation of the problem}

The data transmitted by the Bluetooth device contains fairly comprehensive information about its operation. From the point of view of the problem under discussion, the most important data elements are the unique identifier of the observed device and the relative power level of the signal received from it. Signal power is related to the object-sensor range by the next known ratio [15]:

$$
u=u_{*}-10 \times n \times \log _{10}\left(\frac{d}{d_{*}}\right),
$$

where $u$ is the signal level received by the mobile phone (object) at a distance $d$ from the Bluetooth device (sensor); $u_{*}$ - signal level measured at a distance $d_{*}$ from the device, $\mathrm{n}$ is the coefficient that takes into 
account the propagation of the signal in the environment. The values of the parameters $d_{*}$ and $u_{*}$ calibration distance and signal level are the technical characteristics of a particular device, the value of the attenuation coefficient is also known. In principle, these values can be determined when calibrating the device.

Introduce the right orthogonal $X$ coordinate system associated with the room. Let there be $N$ sensors that are "visible" to the mobile device. The object-sensor range is related to the object and sensor coordinates as follows:

$$
d_{i}=\sqrt{\left(x-x_{i}\right)^{2}+\left(y-y_{i}\right)^{2}}, i=\overline{1, N}
$$

where $x, y$ are the coordinates of the object, $x_{i}, y_{i}$ are the coordinates of the $i$-th sensor.

The measurement equations will look like this:

$$
u_{i}\left(t_{k}\right)=u_{*_{i}}-10 \times n \times \log _{10}\left(\frac{\sqrt{\left(x\left(t_{k}\right)-x_{i}\right)^{2}+\left(y\left(t_{k}\right)-y_{i}\right)^{2}}}{d_{*}}\right)+\eta_{i}\left(t_{k}\right),
$$

where $u_{i}\left(t_{k}\right)$ is the signal level of the $i$-th sensor received at the object at time $t_{k} ; x_{i}, y_{i}$-coordinates of the i-th sensor; $x\left(t_{k}\right), y\left(t_{k}\right)$ - the coordinates of the object at time; $u_{*_{i}}, d_{*_{i}}$ - calibration values of signal level and distance of the $i$-th sensor; $\eta_{i}\left(t_{k}\right)$ - instrumental measurement error of the $\mathrm{i}$-th sensor related to time; $k=\overline{1, M}, M$ - number of measurements from each sensor.

Suppose that the motion of an object is described by the following kinematic model:

$$
\begin{aligned}
& x\left(t_{k+1}\right)=x\left(t_{k}\right)+v_{x}\left(t_{k}\right)\left(t_{k+1}-t_{k}\right), \\
& y\left(t_{k+1}\right)=y\left(t_{k}\right)+v_{y}\left(t_{k}\right)\left(t_{k+1}-t_{k}\right),
\end{aligned}
$$

where $x\left(t_{k}\right), y\left(t_{k}\right)$ - the coordinates of the object at the time $t_{k}, v_{x}\left(t_{k}\right), v_{y}\left(t_{k}\right)$ - the velocity vectors of the object.

The linearization of equation (1) brings it to mind:

$$
\begin{aligned}
& \delta u_{i}\left(t_{k}\right)=\frac{-10 \times n \times d_{*_{i}} \times\left(x\left(t_{k}\right)-x_{i}\right)}{\ln (10) \times\left(\left(x\left(t_{k}\right)-x_{i}\right)^{2}+\left(y\left(t_{k}\right)-y_{i}\right)^{2}\right)} \delta x\left(t_{k}\right)+ \\
& +\frac{-10 \times n \times d_{*_{i}} \times\left(y\left(t_{k}\right)-y_{i}\right)}{\ln (10) \times\left(\left(x\left(t_{k}\right)-x_{i}\right)^{2}+\left(y\left(t_{k}\right)-y_{i}\right)^{2}\right)} \delta y\left(t_{k}\right)+\eta_{i}\left(t_{k}\right)
\end{aligned},
$$

where $\delta x\left(t_{k}\right), \delta y\left(t_{k}\right)$ - errors in a priori ideas about the coordinates of the object; $\delta u_{i}\left(t_{k}\right)$ - measurement error.

Features of the software implementation of this task with the possibility of accumulation and joint processing of measurement data over a period of time making it possible to reduce it to the method of least squares. We write down equation (3) with respect to the model of the evolution of the object coordinates (2):

$$
\begin{aligned}
& \delta u_{i}\left(t_{k}\right)=\frac{-10 \times n \times d_{*_{i}} \times\left(x\left(t_{k}\right)-x_{i}\right)}{\ln (10) \times\left(\left(x\left(t_{k}\right)-x_{i}\right)^{2}+\left(y\left(t_{k}\right)-y_{i}\right)^{2}\right)} \delta x\left(t_{*}\right)+ \\
& +\frac{-10 \times n \times d_{*_{i}} \times\left(x\left(t_{k}\right)-x_{i}\right)}{\ln (10) \times\left(\left(x\left(t_{k}\right)-x_{i}\right)^{2}+\left(y\left(t_{k}\right)-y_{i}\right)^{2}\right)}\left(t_{k}-t_{*}\right) \delta v_{u}\left(t_{*}\right)+ \\
& +\frac{-10 \times n \times d_{*_{i}} \times\left(y\left(t_{k}\right)-y_{i}\right)}{\ln (10) \times\left(\left(x\left(t_{k}\right)-x_{i}\right)^{2}+\left(y\left(t_{k}\right)-y_{i}\right)^{2}\right)} \delta y\left(t_{*}\right)+ \\
& +\frac{-10 \times n \times d_{*_{i}} \times\left(y\left(t_{k}\right)-y_{i}\right)}{\ln (10) \times\left(\left(x\left(t_{k}\right)-x_{i}\right)^{2}+\left(y\left(t_{k}\right)-y_{i}\right)^{2}\right)}\left(t_{k}-t_{*}\right) \delta v_{H}\left(t_{*}\right)+\eta_{i}\left(t_{k}\right)
\end{aligned}
$$


or, in the general case:

$$
\delta Z=H \delta s\left(t_{*}\right)+\xi,
$$

where $\delta Z$ is the complete vector (lengths $M^{\times} N$ ) of the residuals of measurements at the observation interval; $\delta s\left(t_{*}\right)$ - the vector of errors of a priori ideas about the state of the system (coordinates and velocities of the object) at the selected time $t_{*} ; H$ is the coefficient matrix; $\xi$ is the vector of the given measurement errors. The purpose of the solution of problem (4) is to estimate the vector $s\left(t_{*}\right)$ by the available measurements of the signal levels $u_{i}\left(t_{k}\right)$. This estimate can be performed, for example, by reducing the problem to a system of linear algebraic equations:

$$
H^{T} Q^{-1} \delta Z=H^{T} Q^{-1} H \delta s\left(t_{*}\right),
$$

and its solution in known ways. Here, $Q=\left[\xi \xi^{1}\right]$ - the covariance matrix of a random vector $\xi$ is determined by the properties of instrumental measurement errors $\eta_{i}\left(t_{k}\right)$ and is considered known. The matrix $D=\left(H^{T} Q^{-1} H\right)^{-1}$ thus determines the variance of the error of estimation of the state vector in such a way $\delta s\left(t_{*}\right)$, that $D=$ mean $\left.\mid\left(\delta \hat{s}\left(t_{*}\right)-\delta s\left(t_{*}\right)\right)\left(\delta \hat{s}\left(t_{*}\right)-\delta s\left(t_{*}\right)\right)^{T}\right]$ mean it is the operator of mathematical expectation. As the results of the study below shows, the values of the corresponding coefficients of the matrix allow us to estimate the characteristic accuracy of determining the coordinates of the object in the various configurations of the sensor system used for indoor navigation.

\section{Results of research}

The numerical study of the problem was carried out for the following parameter values: instrumental measurement error of the sensors has a normal distribution with a dispersion of $25 \mathrm{dBm} 2$; the signal refresh rate is $0.07 \mathrm{~s}$, which is typical for modern smartphones; the number of measurements $\mathrm{M}$ from each sensor is 28 , which corresponds to the length of the observation interval of approximately 2 seconds.

In Fig. 1 shows the simulated location of the sensors; mimics the typical situation of a $10 \times 10 \mathrm{~m}$ corridor or office.

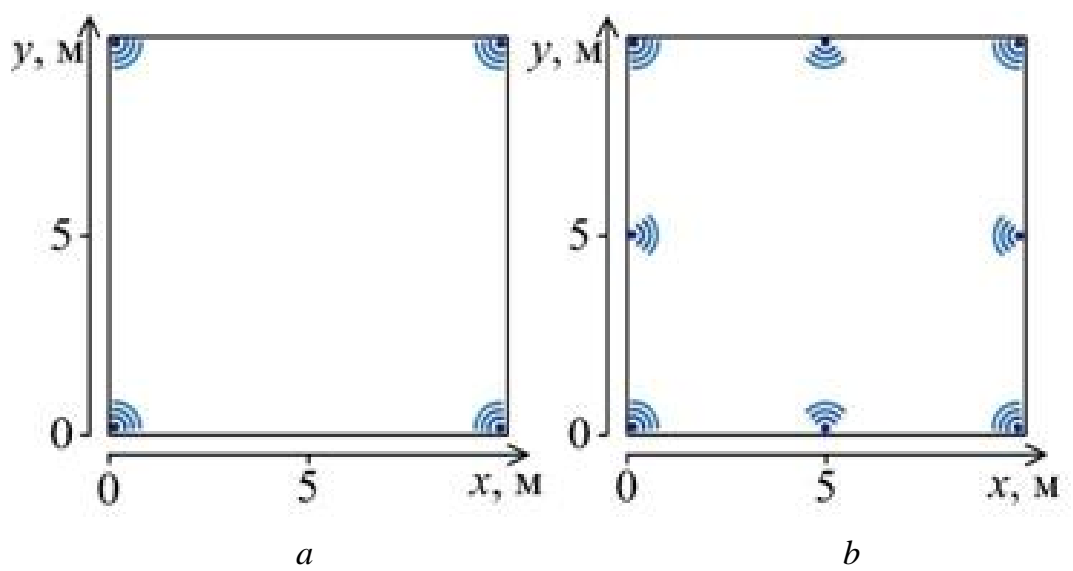

Fig. 1/ Sensor placement options in the hallway or office

Sensors are mounted on the walls in different configurations: in the corners of the server (Fig. 1a), in the corners and on the walls of the server (Fig. 1b). However, the sensors are considered to be in the same plane as the moving object, which limits itself to only a two-dimensional version of the model.

We will consider two variants of the state vector: with components that include coordinates and velocities of the object, and with components that include coordinates only. 
In Fig. Figure 2 shows the values of the average error of estimating the coordinates of an object in a kinematic problem when finding an object in a room (Fig. 1). Thus fig. Fig. 2a corresponds to the configuration of the sensors. $1 \mathrm{a}$, and Fig. $2 \mathrm{~b}$ - configuration $1 \mathrm{~b}$. The value takes values from 1.9 to 2.5 meters for the case of four sensors and from 0.9 to 1.2 meters for a room with eight sensors.
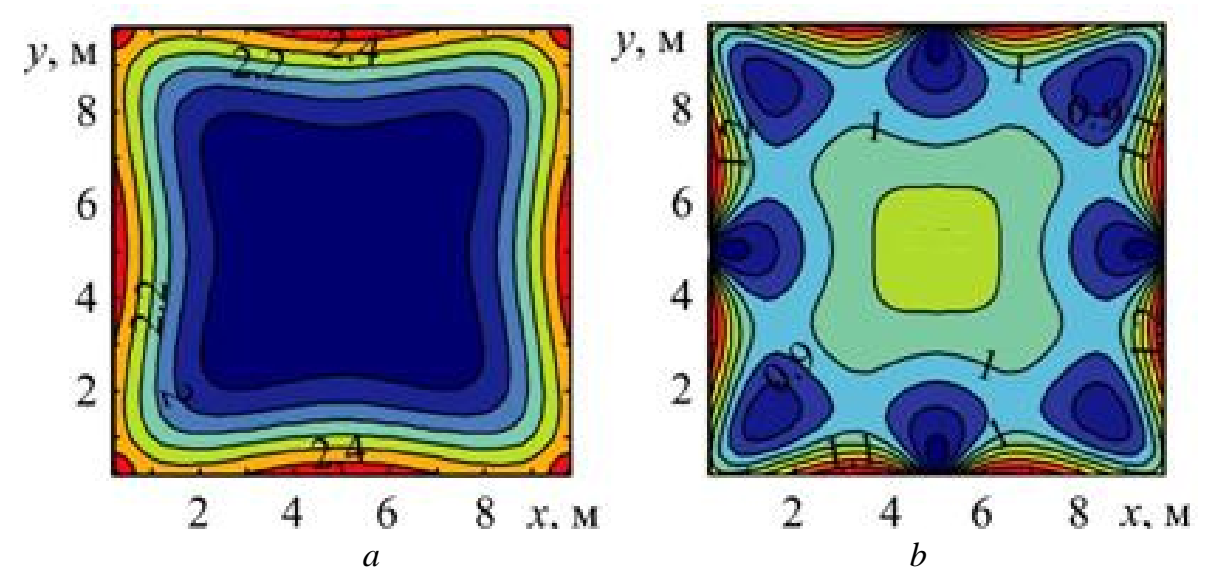

Fig. 2/ Error in determining the coordinates in the office when estimating the coordinates and velocities of the object

Similar values are given in Fig. 3. It can be seen that in the latter case they are approximately twice less than in the kinematic task.
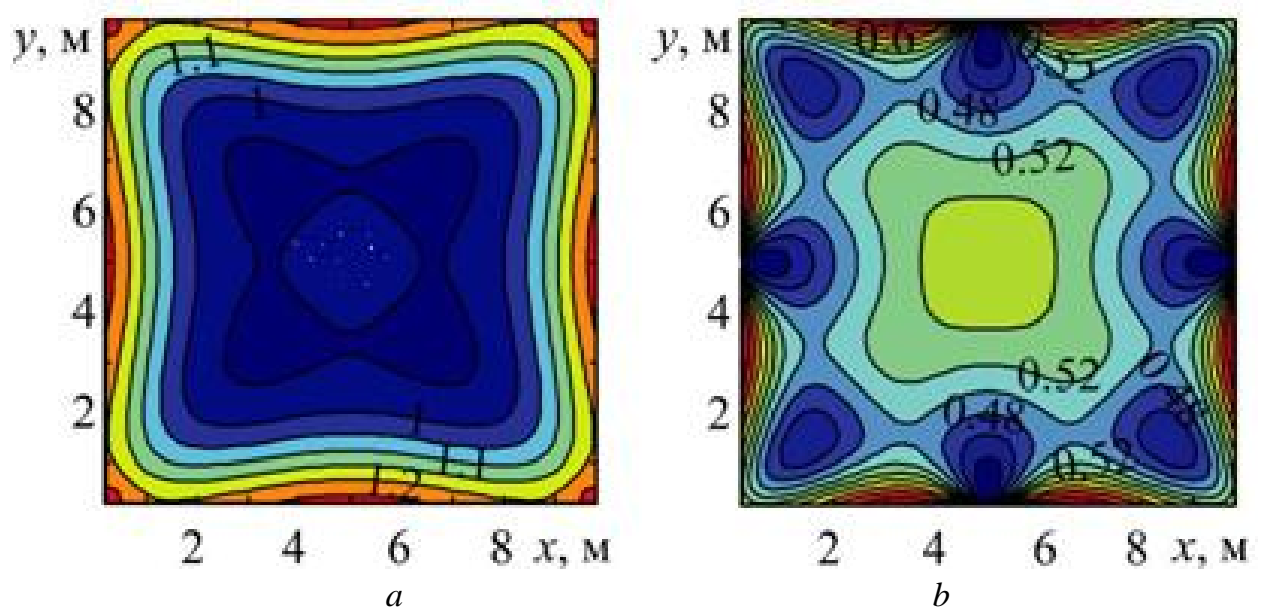

Fig. 3 Error in determining coordinates in the office when estimating the coordinates of the object

In general, the expected error of coordinate estimation should be considered acceptable for a large number of practical applications.

The research used SKYLAB Beacon VG01 Bluetooth beacons and a Samsung Galaxy S8 smartphone on the Android platform. Several preliminary tests of the functioning of the system were carried out for different variants of implementation of algorithms for determining the path and positioning, during which the errors of navigation definitions were evaluated first of all. The best results are obtained when using a combination of positioning models with corrections from Bluetooth positioning data by the method of prints using the modified method of K-nearest neighbors. The results of the tests show that the optimal filter compensates for errors and corrects the positioning card from Bluetooth beacons. When passing the specified route, the maximum error did not exceed $1 \ldots 1.5 \mathrm{~m}$. 
In Fig. 4 shows a recording of the movement (thin dark line) along an empty corridor and office of one of the malls, pre-equipped with seven evenly spaced Bluetooth beacons. Motion on the trajectory AB (thick line) was carried out without stopping at a speed of movement of $1.2 \ldots 1.5 \mathrm{~m} / \mathrm{s}$.

At the same time, the navigation error of the system for the same route does not exceed 3 meters on average. Acceptable results were also obtained for Bluetooth positioning at distances of beacons from 1 to 10 meters. However, these data were characterized by relative instability due to the presence of obstacles and moving people.

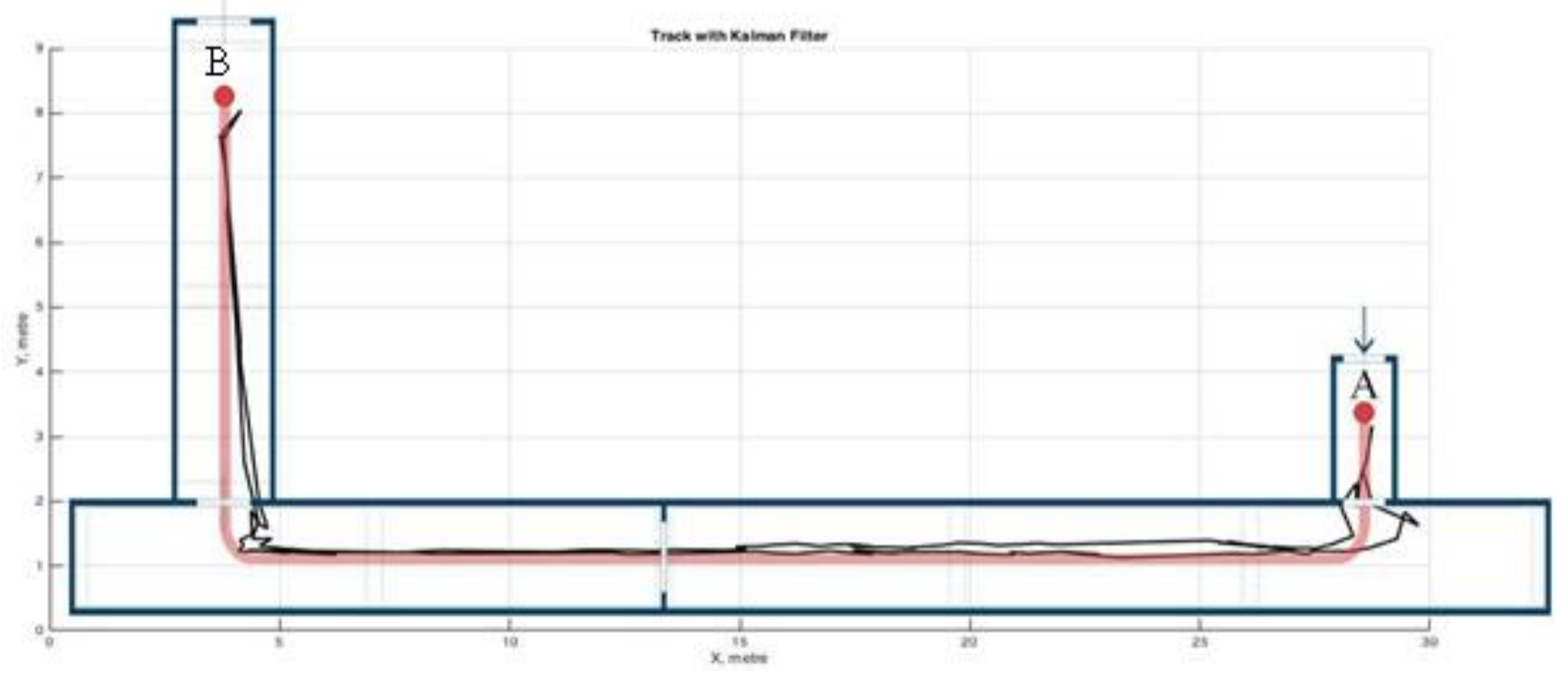

Fig. 4. Recording the trajectory of traffic in the forward and reverse directions along the corridor in optimal filtration mode

In Fig. 5 shows the result of evaluating the coordinates of an object in an office when solving a kinematic problem. The dots show estimates of the location of the object, with the object in the middle of the office. Fig. 5a corresponds to the case of four beacons in the corners of the office, Fig. 5b - the case of eight beacons.
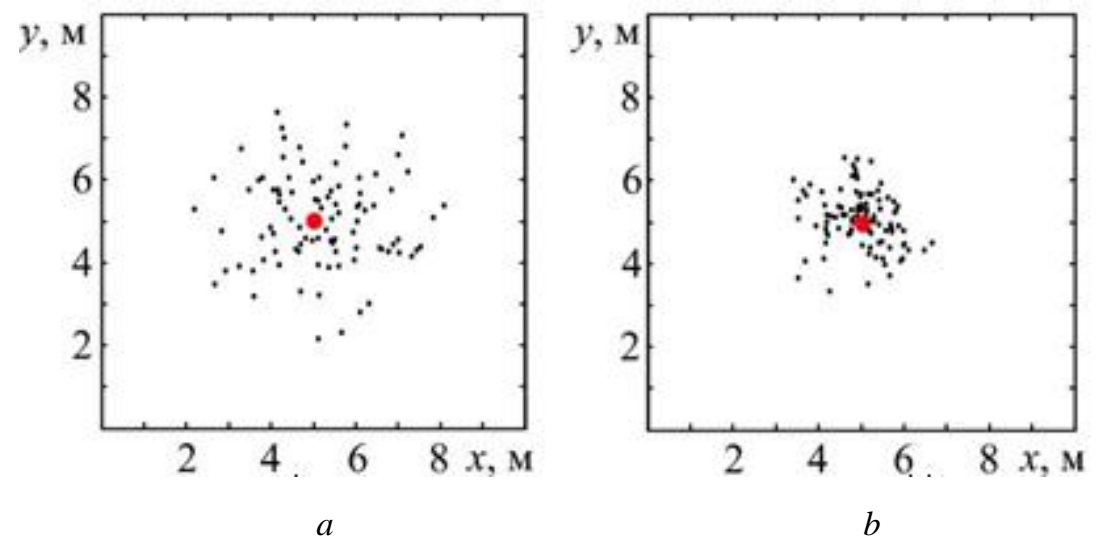

Fig. 5 The results of the evaluation of the coordinates of the object in the office when evaluating the coordinates and velocities of the object

Fig. 6 shows a similar result of estimating the coordinates of an object when solving a static problem. 

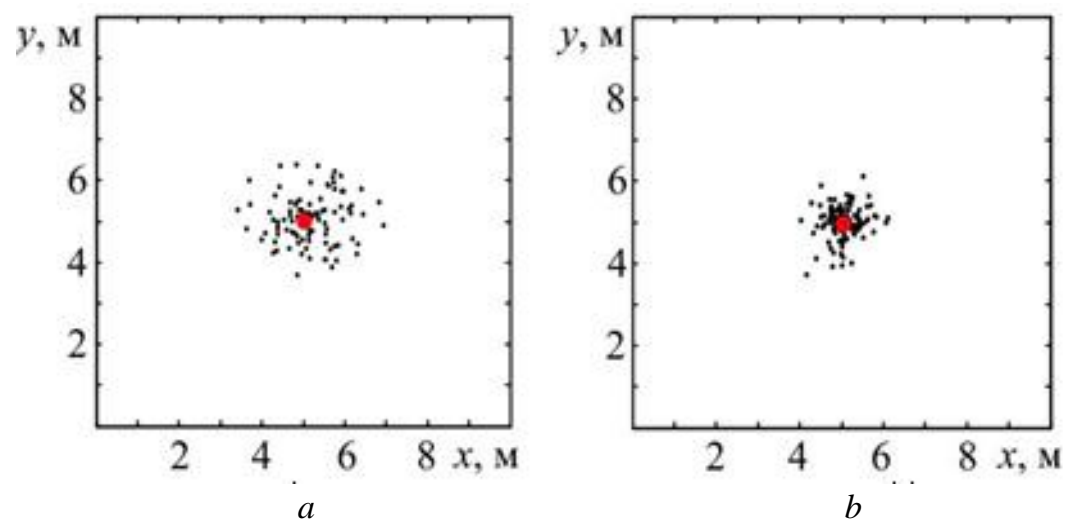

Fig. 6 The results of estimating the coordinates of the object in the office when evaluating the coordinates of the object

From the results of the tests, we can conclude that the error of estimating the coordinates of the object in the field experiment is completely in accordance with the predicted calculations. When analyzing Fig. 2 and 5, 3 and 6 show that the error of coordinate estimation falls in the circle with the same radius. This confirms the possibility of using such estimates when designing the navigation system under consideration.

The accuracy of solving a static problem is significantly higher (approximately 2 times) than kinematic. On the other hand, ignoring the object's velocity task model in its real motion leads to its unsatisfactory solution. Therefore, when designing an application that navigates a smartphone, it is imperative to identify the movement model. For static objects in the observation interval, you can limit yourself to a static model, and for moving objects to use a kinematic model.

\section{Conclusions}

The results of this study allow us to optimistically evaluate the possibility of building a navigation system based on Bluetooth beacons in smartphones and mobile phones using classic model ideas about moving objects positioning systems. At a given distance between beacons and an object of $5 \mathrm{~m}$, the real-world accuracy of determining the coordinates of the object is $1-2 \mathrm{~m}$, which is sufficient for traditional navigation tasks inside buildings. Further enhancement of navigation accuracy may be associated with the reduction of the random component of instrumental measurement errors by identifying the signal model and applying different filtering algorithms. Improving navigation accuracy to values of about $0.5 \mathrm{~m}$, in the long run, would qualitatively extend the range of tasks to be solved.

It should also be noted that the construction of this type of navigation system is always linked to the attachment of the sensors to the local coordinate system (positioning maps). This binding can be accomplished in various known ways.

The experimental results indicate that the proposed algorithm, based on the use of data from the micromechanical inertial sensors of the smartphone, showed the worst results. Using more accurate inertial sensors and a more complete model of erroneous positioning in conjunction with a Bluetooth beacon corrector can produce more acceptable results. But this will require the use of large computing power, which may not be acceptable for a consumer mobile device.

The accuracy of positioning using the proposed system is higher than the existing algorithm. The maximum deviation from the actual route of the route is no more than 3 meters.

The integrated use of positioning systems with positioning data on Bluetooth beacons allows for optimal navigation filtration to obtain navigation accuracy in the room within $1 \ldots 1.5 \mathrm{~m}$. beacon spaces based on smartphones with specialized positioning systems and appropriate mapping support.

1. Belej O. Protecting Data Transmission in Sensory Networks by MQTT-Protocol // матеріали VII міжнародної науково-технічної конференції «Захист інформаџії і безпека інформачійних систем», Львів 30 31 травня 2019 р. - Львів : Видавництво Львівської політехніки, 2019. - с. 74-78.

2. Belej O., Nestor N. and Polotai O. Developing a Local Positioning Algorithm Based on the Identification of Objects in a Wi-Fi Network of the Mall. 2019 IEEE XVth International Conference on the Perspective Technologies 
and Methods in MEMS Design (MEMSTECH), Polyana, Ukraine, 2019, pp. 32-36. - doi: 10.1109/MEMSTECH.2019.8817385.

3. Belej O., Nestor N., Polotai O. and Sadeckii J.Features of Application of Data Transmission Protocols in Wireless Networks of Sensors. 2019 3rd International Conference on Advanced Information and Communications Technologies (AICT), Lviv, Ukraine, 2019, pp. 317-322. - doi: 10.1109/AIACT.2019.8847878.

4. Belej O.I. Formation of the signal of information transmission in the system of hyperbolic chaos. INFOS2019: Збірник тез доповідей учасників Міжнародного форуму з інформаційних систем $і$ технологій, м. Харків, 24-27 квітня 2019 року. - Харків, 2019. - с. 11-15.

5. Cantón Paterna V. et al. A Bluetooth Low Energy Indoor Positioning System with Channel Diversity, Weighted Trilateration, and Kalman Filtering //Sensors. - 2017. - T. 17. - №. 12. - C. 2927.

6. Detect Framework, In Proceedings of the 2008 IEEE 24th International Conference on Data Engineering (ICDE) (April 2008, Cancun, Mexico), IEEE Comp. Soc., 140-149, 2008.

7. Detect Framework, In Proceedings of the 2008 IEEE 24th International Conference on Data Engineering (ICDE) (April 2008, Cancun, Mexico), IEEE Comp. Soc., 140-149, 2008.

8. Gu Y., Lo A., Niemegeers I. A survey of indoor positioning systems for wireless personal networks. IEEE Commun. Surv. Tutor. 2009, 11, 13-32.

9. Kim J., Jun H., "Vision-based location positioning using augmented reality for indoor navigation", IEEE Trans. Consum. Electron, 2008, vol. 54, pp. 954-962.

10. Li C.-L., Laoudias C., Larkou G., et al. Indoor Geolocation on Multi-sensor Smartphones / Proceeding of the 11th Annual International Conference on Mobile Systems, Applications, and Services. New York, NY, USA: ACM, 2013. P. 503-504.

11. Maggi F. M., Montali M., Westergaard M. Monitoring business constraints with linear temporal logic: An approach based on colored automata» in Proc. of the 9th International Conference on Business Process Management (BPM'11), Clermont-Ferrand, France, LNCS, vol. 6896. Springer, August-September 2011, pp. 132-147.

12. Qi J., Liu G.P. "A Robust High-Accuracy Ultrasound Indoor Positioning System Based on a Wireless Sensor Network”, Sensors, 2017, vol. 17, pp. 25-54.

13. Vanamalini T.S., Lakshmi K. Joshitha. RSSI Aided Cartographic In-door Tracking System using Wireless Sensor Network // International Journal of Engineering Research \& Technology (IJERT). 2015. Vol. 4. Issue 03.

14. Verbeek H., Buijs J., Dongen B., and Aalst W. Xes, sesame, and prom 6» in Proc. of the CAiSE Forum on Information Systems Evolution, Hammamet, Tunisia, LNBIP, vol. 72. Springer, June 2010, pp. 60-75.

15. Xin Li, Jian Wang, and Chunyan Liu. A Bluetooth/PDR Integration Algorithm for an Indoor Positioning System // J

ournal Sensors. 2015. №15.

О. Белей, К. Колесник

Національний університет "Л ьвівська політехніка"

\section{ЗАСТОСУВАННЯ СМАРТФОНІВ ДЛЯ ПОЗИЦІЮВАННЯ В СЕРЕДИНІ ПРИМІЩЕННЯ}

(C) Белей О., Колесник К., 2020

Статтю присвячено проблемі навігації усередині приміщень в умовах недоступності сигналу супутникових засобів. У цьому випадку для визначення місця розташування об'сктів використовуються альтернативні джерела їх позиціювання. Використання для задач навігації усередині приміщень смартфонів дозволяє отримати вичерпні дані про його роботу. Для вирішення завдання навігації найбільш важливими елементами масивів даних с унікальний ідентифікатор спостережуваного пристрою і відносний рівень потужності прийнятого від нього сигналу. Дані розрахунків та експериментів показують, що навігаційні вимірювання 3 допомогою смартфонів дають можливість якісного вирішення завдання спостереження на заданих відстанях між датчиками, які не перевищують 5-7 метрів. При цьому важливими є взаємне розташування датчиків і рухомих об’єктів. При відстані між маяками і об'єктом 5 м реально досяжна точність визначення координат об'скту складає 1-2 м, що с достатньою умовою для традиційних завдань навігації в середині будівель.

Ключові слова - інформаційна система, навігація всередині приміщень, датчики, смартфон, сигнал, координати, швидкість, метод найменших квадратів. 